\title{
TRIBAL ENERGY EFFICIENCY AND RENEWABLE ENERGY DEVELOPMENT ON TRIBAL LANDS
}
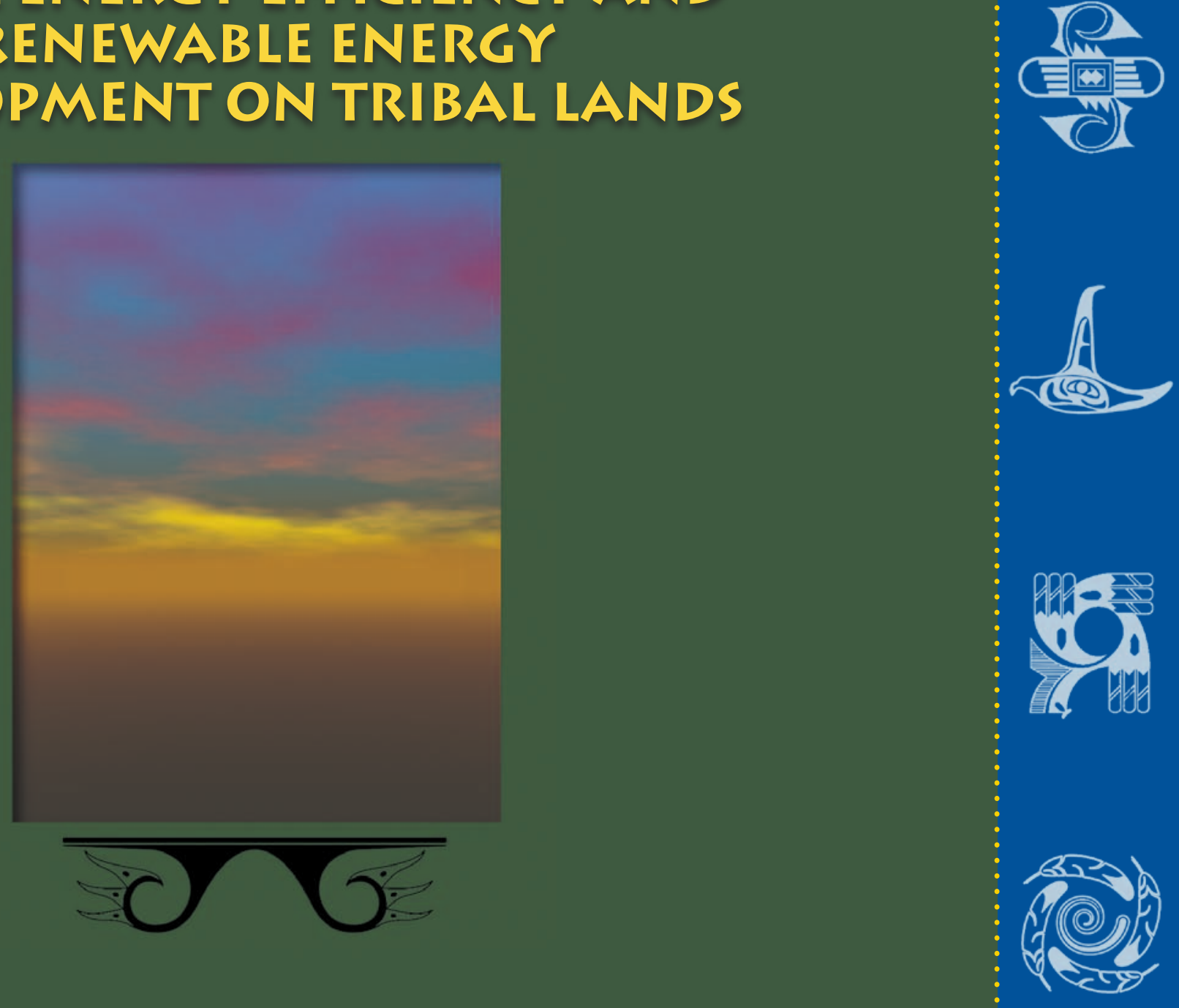


\section{Our Mission \\ To offer financial and technical assistance to Tribes through government-to-government partnerships that}

1) Empower Tribal leaders to make informed decisions about energy choices

2) Bring renewable energy and energy efficiency options to Indian Country

3) Enhance human capacity through education and training

4) Improve local Tribal economies and the environment

5) Make a difference in the quality of life of Native Americans. 


\section{Purpose}

The program promotes Tribal energy sufficiency, economic development, and employment on Tribal lands through the use of renewable energy and energy efficiency technologies.

The Tribal Energy Program, under the Department of Energy's (DOE's) Office of Energy Efficiency and Renewable Energy, provides financial and technical assistance to Tribes to evaluate and develop their renewable energy resources and reduce their energy consumption through efficiency and weatherization.

As building knowledge and skills is essential to developing, implementing, and sustaining energy efficiency and renewable energy projects, the program also offers education and training opportunities.

\section{Policy}

The Department of Energy's

American Indian and Alaska Native

Tribal Government Policy sets forth principles to be followed by DOE to ensure effective implementation of governmentto-government relationships with American Indians and Alaska Native Tribal governments. Through the authorities set forth in the Energy Policy Acts and Executive Orders, DOE is seeking to support energy sufficiency on Tribal lands and support the trust responsibility set forth in DOE's American Indian and Alaska Native Tribal Government Policy.

For DOE's policy, visit www.eere.energy.gov/ tribalenergy/policy.cfm 


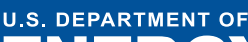 ENERGY \\ Energy Efficiency \& \\ Renewable Energy}

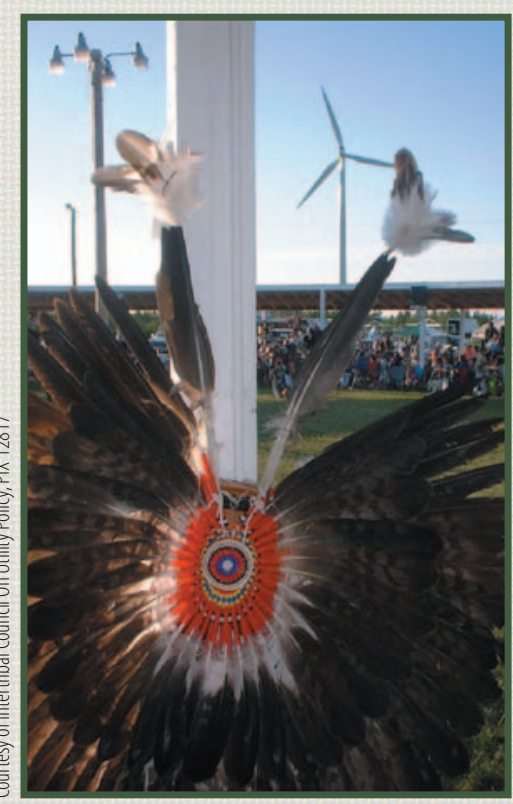

DOE has funded

129 Tribal energy projects totaling $\$ 30$ million (2002 to 2010)

Type of Project:

First Steps -42

Feasibility -68

Turbine installed at Rosebud Sioux

Reservation in

South Dakota

Development - 11

Deployment - 8
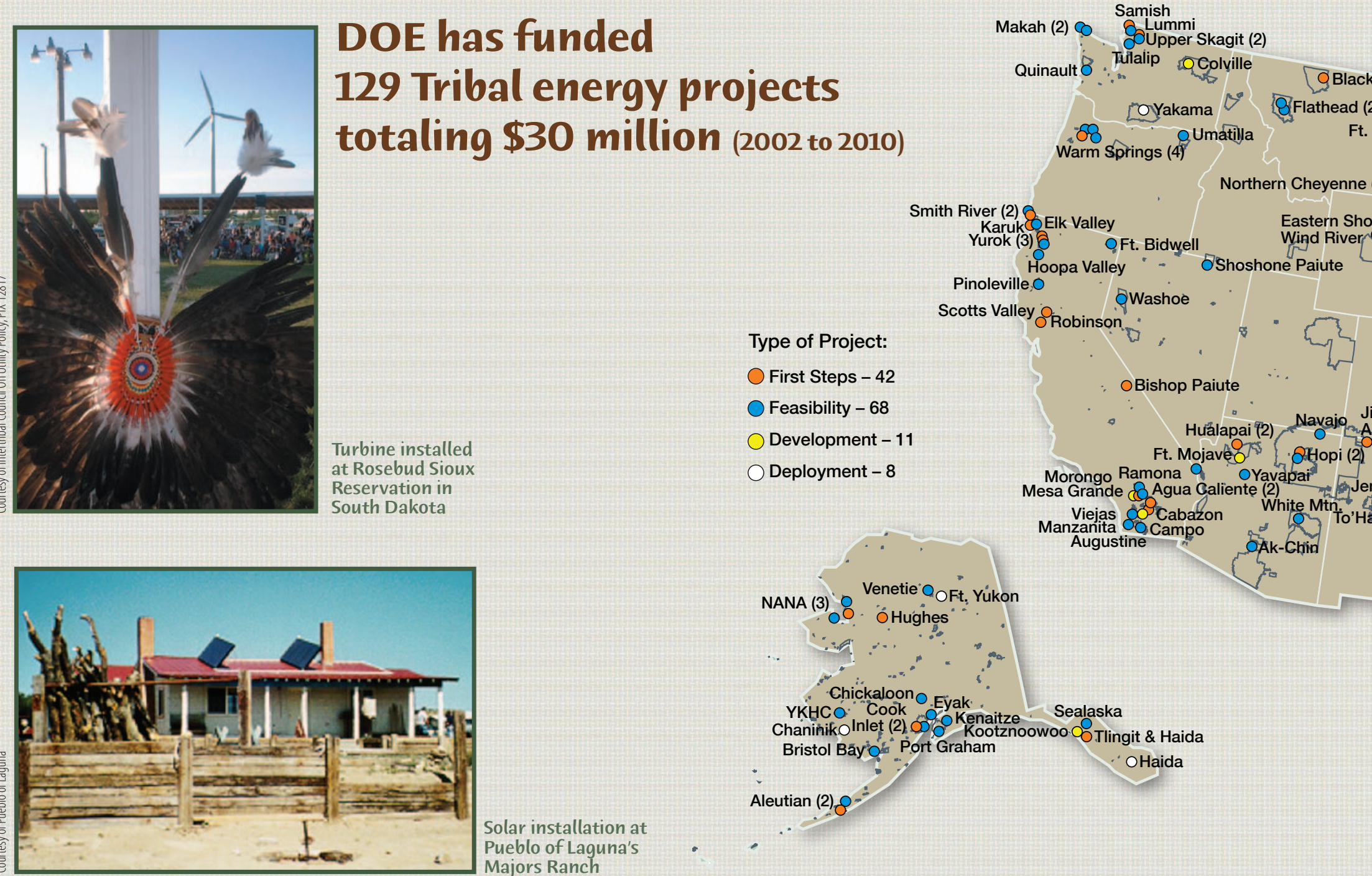

Solar installation at Pueblo of Laguna's

Pinoleville Hoopa Valley "Scotts Valley WWashoe

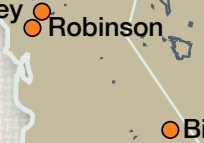

OBishop Paiute

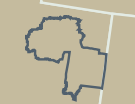

lapai (2) Navajo J t. Mojavẩ Morongo Ramona Q OYavapai Mesa Grande \& Agua Galiente (2) White Mtn.

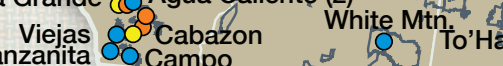
Manzanita Compo

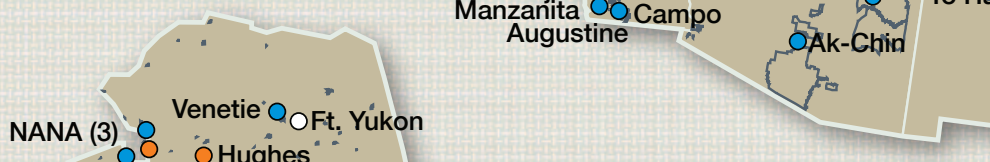

NANA (3) OD. 'Ó Hugh OFt, Yúko

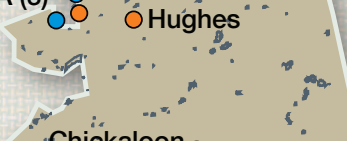

Chaninikik Inlet (2) Kootznoowoo 00.Tlingit \& Haida

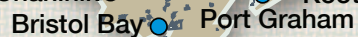
OHaida

\section{Aleutian (2)}

Majors Ranch 


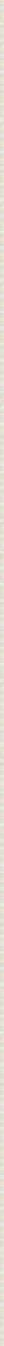




\section{U.S. DEPARTMENT OF

\section{Wind Energy}

Wind energy uses the energy in the wind for generating electricity, charging batteries, pumping water, or grinding grain. Large, modern wind turbines operate together in wind farms to produce electricity for utilities. Small turbines are used by homeowners and remote villages to help meet energy needs.

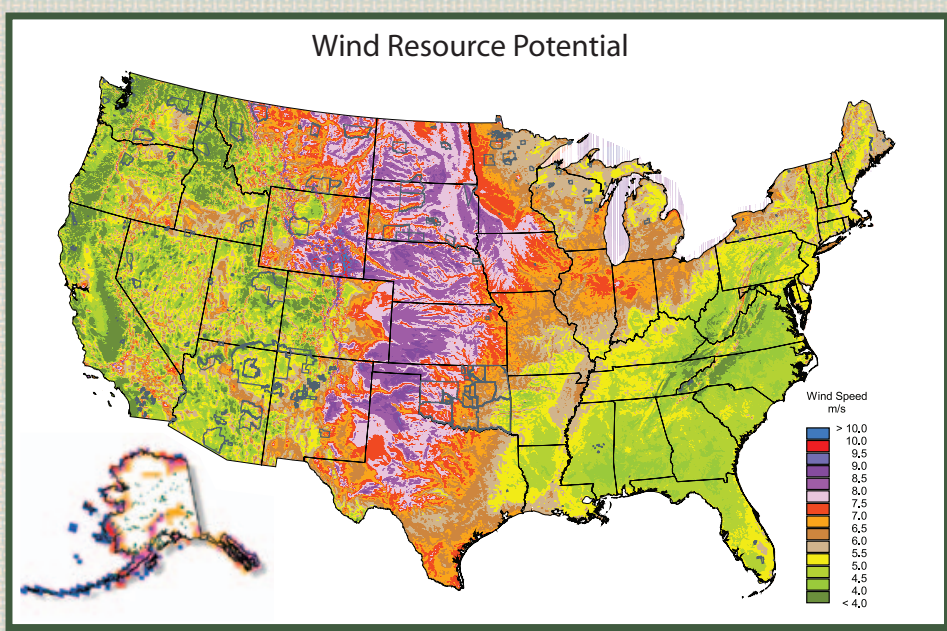

Areas designated class 4 or greater are suitable for most utilityscale wind turbine applications, whereas class 2 and 3 areas are marginal for utility-scale applications but may be suitable for remote applications.

\section{Solar Energy}

A square area in the Southwest 100 miles on each side could generate all the electricity used in the United States! Sunshine varies across the United States by about a factor of two, while utility rates vary by about a factor of 10 . Solar opportunities may exist in places you would not initially expect based only on resource assumptions.

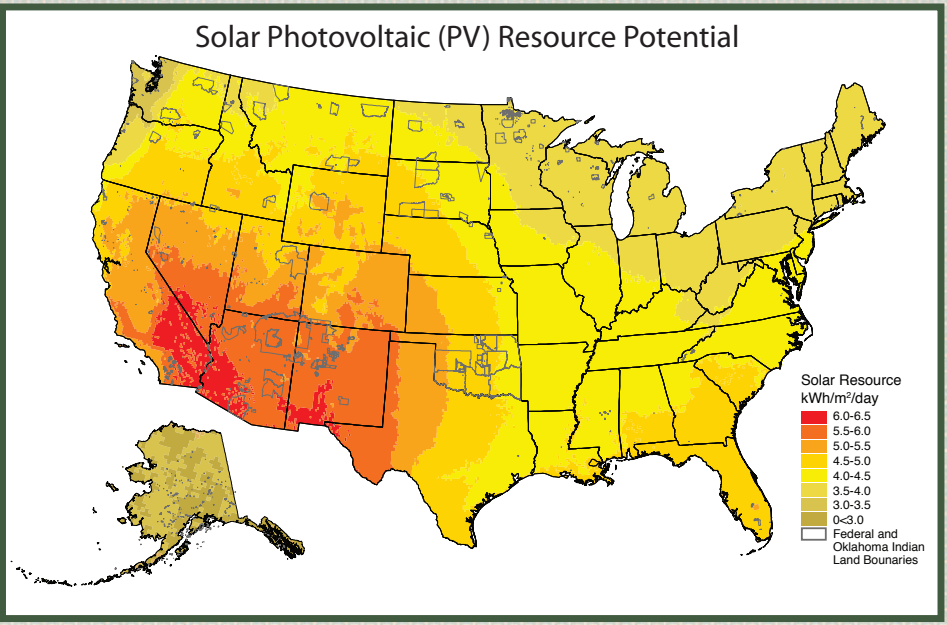

A distance from the nearest utility line of only a quarter mile raises electricity distribution costs sufficiently to make PV cost-effective for small loads, even in the cloudiest parts of the country.

For resource information, visit DOE's

Guide to Tribal Energy Development at www.eere.energy.gov/tribalenergy/guide 


\section{Biomass}

Biomass offers the opportunity to produce fuel, electric power, chemicals, and other industrial materials from renewable resources including agricultural crops and residues, trees and forest residues, grasses, animal wastes, and organic municipal solid wastes. Fuel products include ethanol, which can be produced from wood chips, rice straw, switchgrass, sugar cane waste, and corn; and renewable biodiesel, which can be produced from grain and grain products.

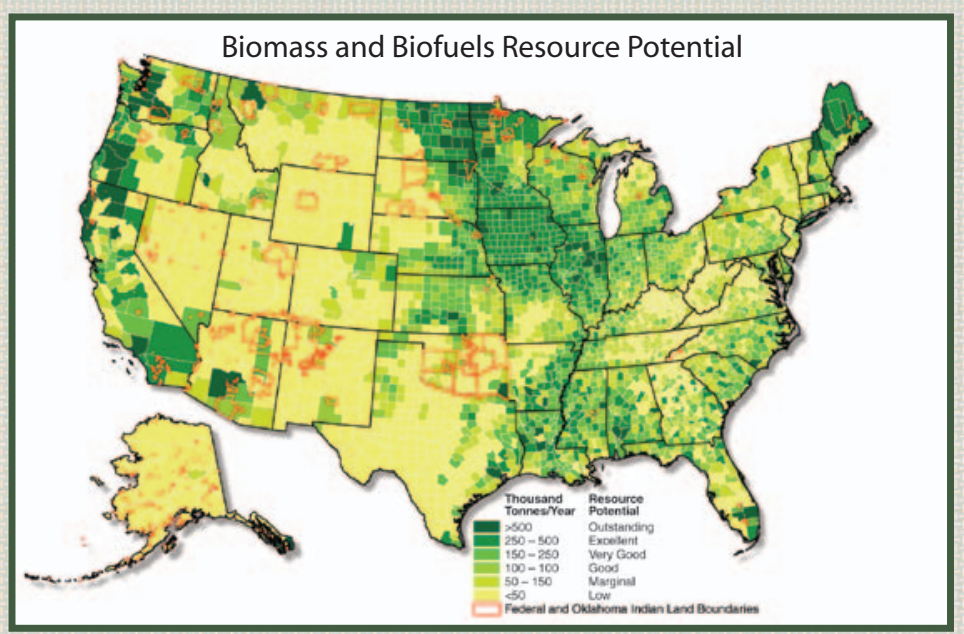

Today, various forms of biomass energy account for $45 \%$ of renewable energy used in the United States. Biomass resources must be assessed on a case-by-case basis. The most economical resources are often associated with residual materials from commercial or industrial processes.

\section{Hydropower}

Hydropower plants capture the kinetic energy of falling water to generate electricity, using a turbine and a generator to convert the energy from the water to mechanical and then electrical energy. Hydropower currently contributes the greatest share of renewable electricity generation in the United States. For more information, see http://hydropower.inel.gov/prospector/index.shtml

\section{Geothermal Energy}

Geo- (Earth) thermal (heat) energy is an enormous, underused heat and power resource that is clean, reliable, and homegrown (making us less dependent on fossil fuel). Earth's energy can be converted into heat and electricity. The three technology categories are geothermal heat pumps, direct-use applications, and electricity production.

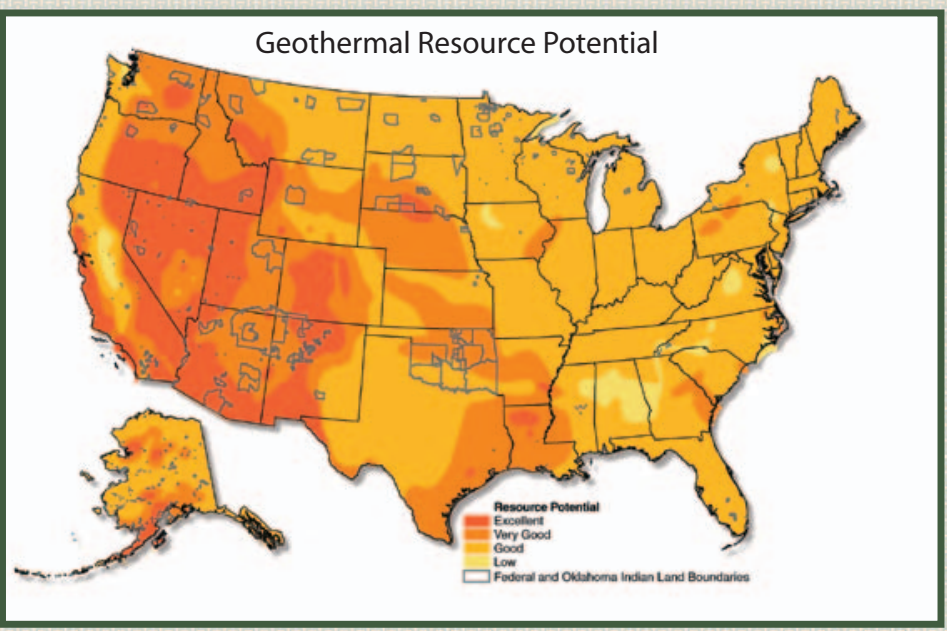

Geothermal (or ground source) heat pumps use temperatures found a few feet below the surface to transfer heat from the ground to the building in winter and from the building to the ground in summer. The rate of installation of ground-source heat pumps is thought to be between 10,000 and 40,000 per year. Direct-use geothermal resources can be used to heat buildings, melt snow, grow plants in greenhouses, dehydrate onions and garlic, heat water for fish farming, and pasteurize milk. Utility-scale electric power can be produced using deep wells drilled into underground reservoirs to tap steam and very hot water to drive turbines and generators. 


\section{Funding Opportunities}

- Funding for the evaluation, development, and deployment of renewable energy and efficiency projects on Tribal lands is provided to Tribes on a competitive basis.

- Each funding opportunity announcement will identify submission requirements, eligibility, rating criteria, and cost share, if any.

\section{Education and Training}

- Student internships

See the Web site for information and application form.

\section{- Regional workshops and Webinars}

The Tribal Energy Program conducts periodic workshops and Webinars for Tribes to learn about renewable energy and energy efficiency and how to develop those resources.

\section{- Renewable energy short courses}

Short courses are posted on the Web site. Courses cover renewable energy and efficiency options, business development, and project financing.

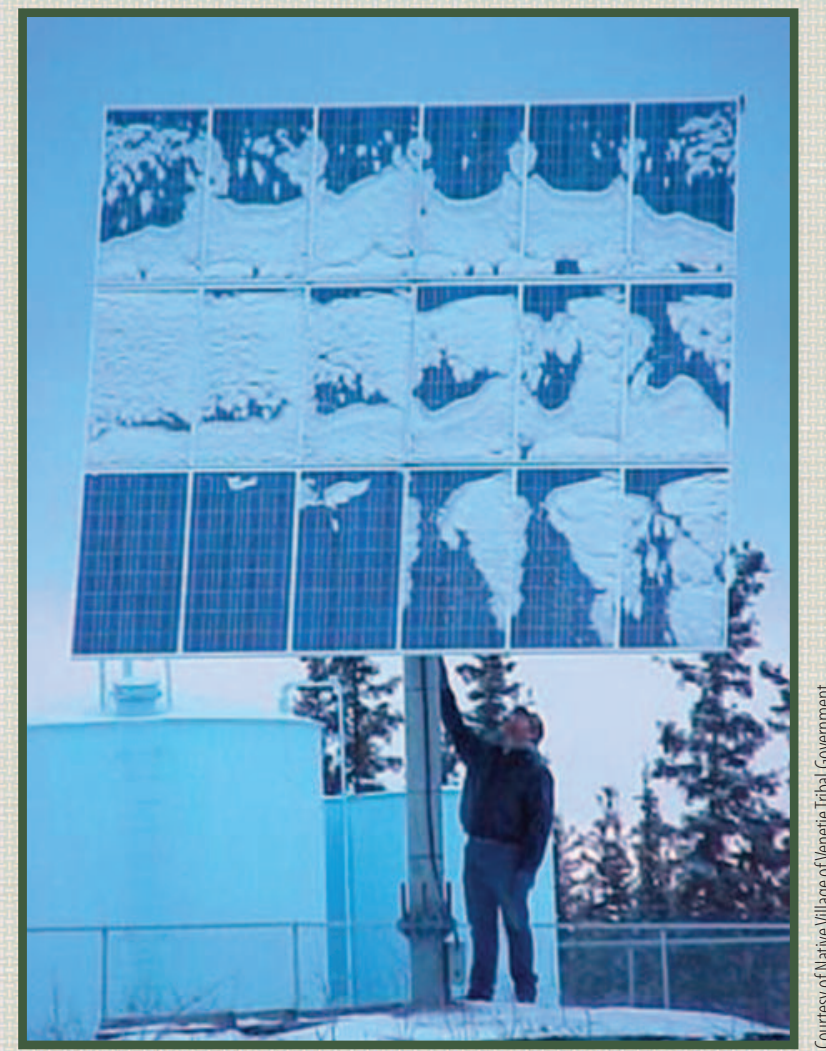

One of the world's northern-most Tribally owned solar systems (Native Village of Venetie, AK)

For information on funding and training opportunities, visit the Trbal Energy Program Web site at www.eere.energy.gov/tribalenergy 


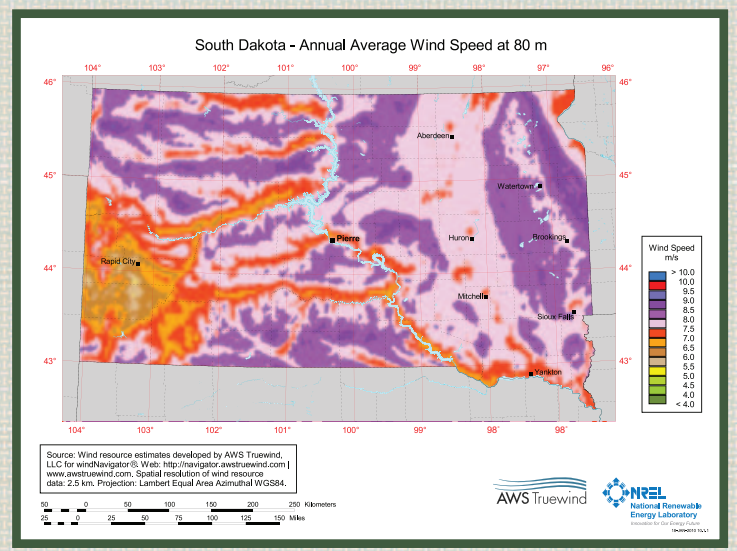

High-resolution wind prospecting maps are available for most Tribal regions.

\section{National Laboratory Technical Assistance}

- Strategic energy planning

- Renewable energy technology information

- Renewable resource information

- Project support

- Economic evaluations

- Design review

- Special studies

Assistance provided upon request based on resource availability. See Web site for instructions on submitting a request.

\section{Information}

- Tribal Energy Program Web site www.eere.energy.gov/tribalenergy

- Upcoming events

- Program information

- Funding opportunities

- Project summaries

- Project contacts and reports

- Information resources

- Training opportunities

- Program contacts

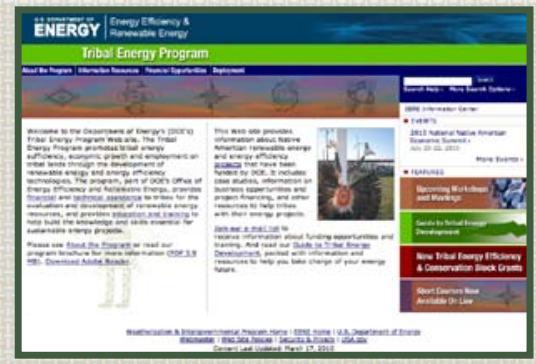

\section{- Guide to Tribal Energy Development} www.eere.energy.gov/tribalenergy/guide

- Development process

- Strategic planning

- Options analysis

- Organizational development

- Project development

- Resource library

- Energy resources

- Technologies

- Cost

- Risk factors

- Legal issues

- Financing options

- Contacts

- Case studies
Strategic Planning

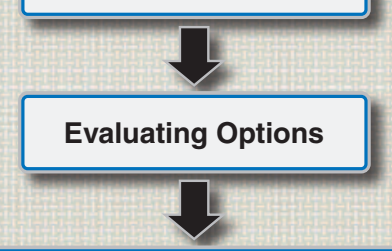

Organizational Development

Project Development 
The Tribal Energy Program consists of program management through DOE headquarters, program implementation through the DOE Golden Field Office, and technical support through DOE's National Renewable Energy Laboratory (NREL) and Sandia National Laboratories (SNL).

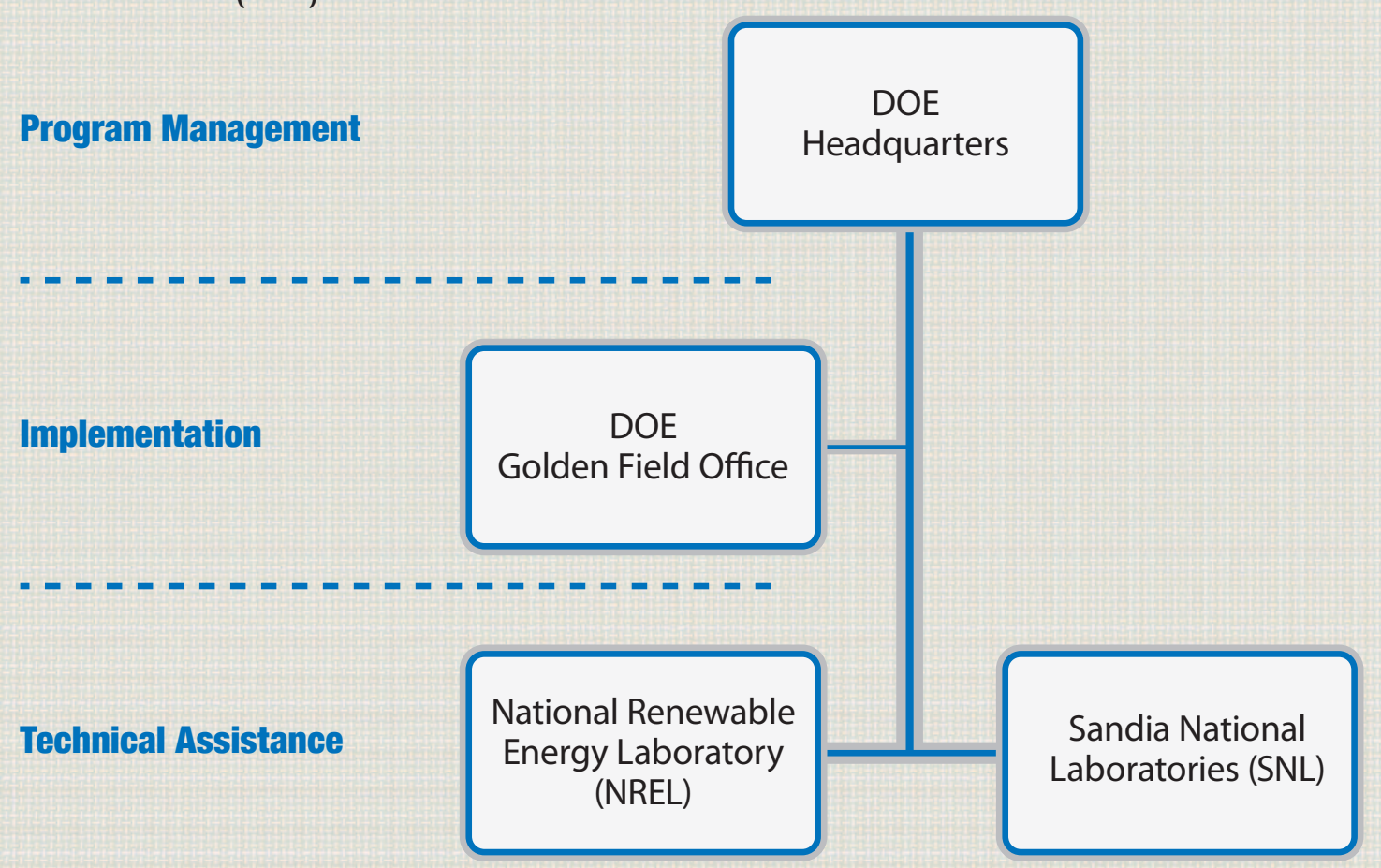

\section{Tribal Energy Program Organization}

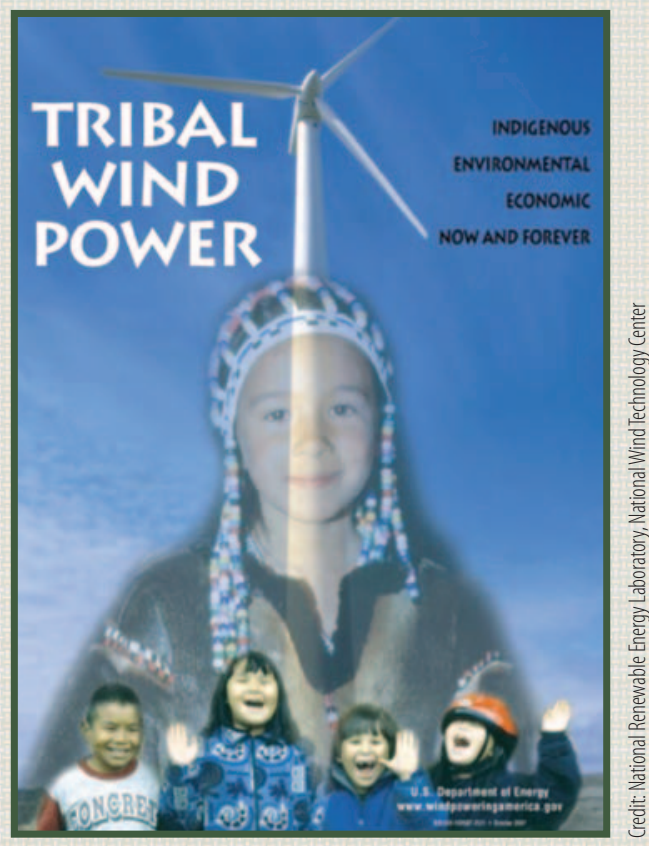

For contact information, see www.eere.energy.gov/tribalenergy/contacts.cfm 
For more information on the Tribal Energy Program visit our Web site at www.eere.energy.gov/tribalenergy

To receive periodic information on funding opportunities, upcoming workshops and training, and other Tribal energy information, join our e-mail list from the Web site home page. 

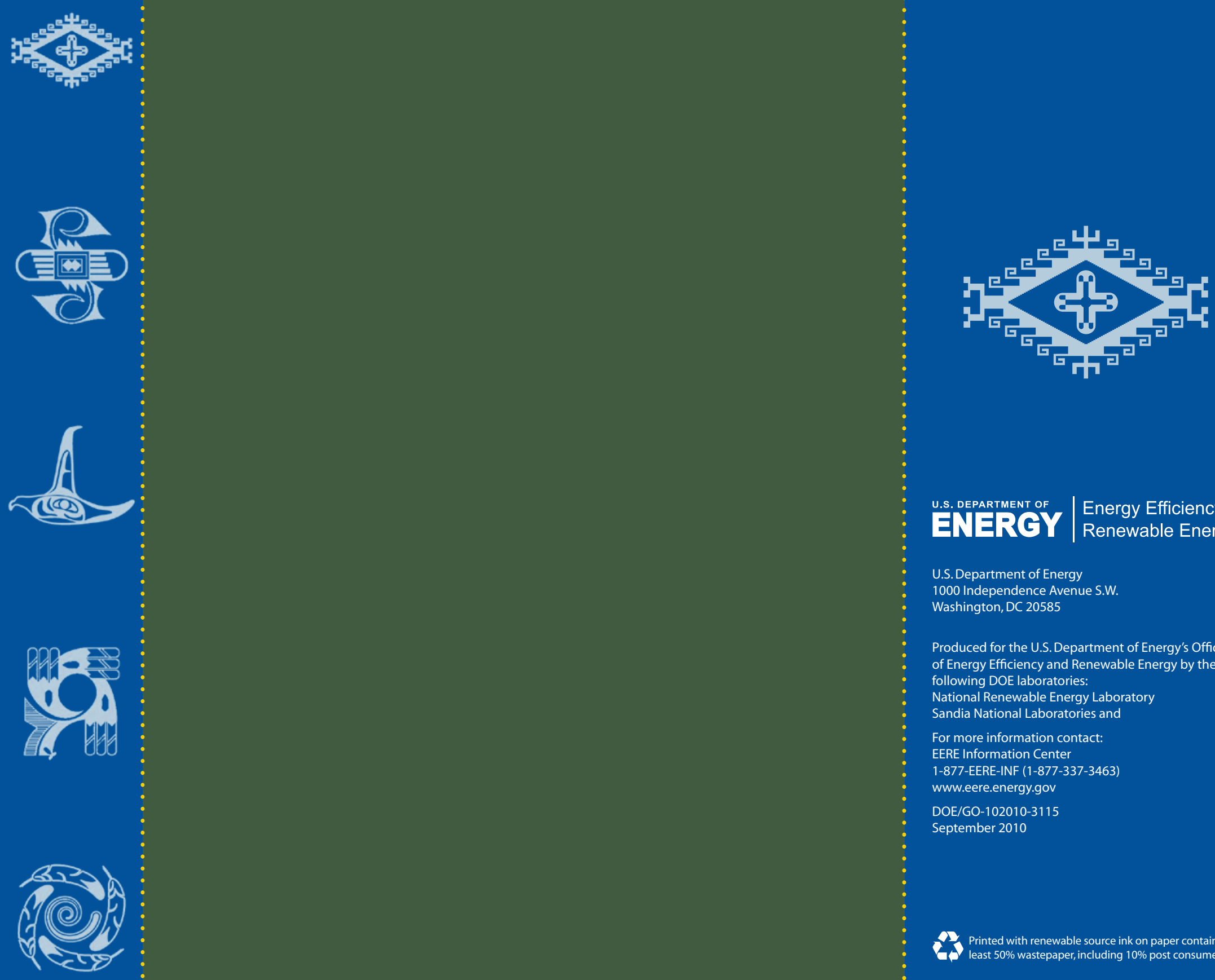

\section{U.s. DEPARTMENT OF | Energy Efficiency \&}

U.S. Department of Energy

1000 Independence Avenue S.W.

Washington, DC 20585

Produced for the U.S. Department of Energy's Office of Energy Efficiency and Renewable Energy by the following DOE laboratories:

National Renewable Energy Laboratory

Sandia National Laboratories and

For more information contact:

EERE Information Center

1-877-EERE-INF (1-877-337-3463)

www.eere.energy.gov

DOE/GO-102010-3115

September 2010

Printed with renewable source ink on paper containing at least $50 \%$ wastepaper, including $10 \%$ post consumer waste. 